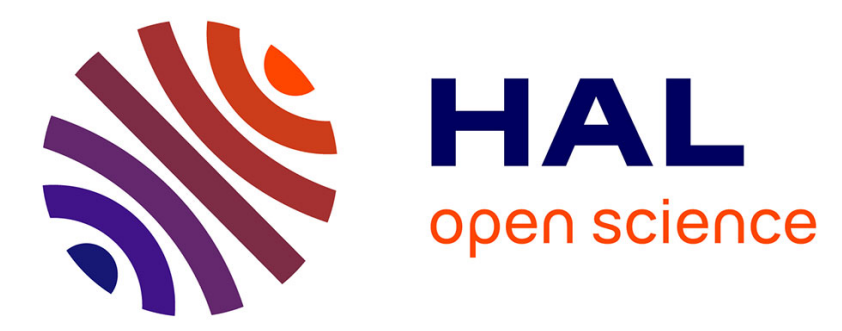

\title{
Accounting for complex environmental exposure situations: a classification approach
}

Benoit Lalloue, Jean-Marie Monnez, Cindy M. Padilla, Wahida Kihal, Denis

\author{
Zmirou-Navier, Séverine Deguen
}

\section{To cite this version:}

Benoit Lalloue, Jean-Marie Monnez, Cindy M. Padilla, Wahida Kihal, Denis Zmirou-Navier, et al.. Accounting for complex environmental exposure situations: a classification approach. Environment and Health - Bridging South, North, East and West. Conference of ISEE, ISES and ISIAQ., Aug 2013, Basel, Switzerland. , 2013. hal-01432884

\section{HAL Id: hal-01432884 \\ https://hal.science/hal-01432884}

Submitted on 12 Jan 2017

HAL is a multi-disciplinary open access archive for the deposit and dissemination of scientific research documents, whether they are published or not. The documents may come from teaching and research institutions in France or abroad, or from public or private research centers.
L'archive ouverte pluridisciplinaire HAL, est destinée au dépôt et à la diffusion de documents scientifiques de niveau recherche, publiés ou non, émanant des établissements d'enseignement et de recherche français ou étrangers, des laboratoires publics ou privés. 
${ }^{1}$ EHESP Rennes, Sorbonne Paris Cité, France

${ }^{2}$ Inserm, UMR 1085-IRSET (Institut de recherche sur la santé l'environnement et le travail), France

E HE S P ${ }^{3}$ Lorraine University, CNRS UMR 7502, Institut Elie Cartan, France ${ }^{5}$ Lorraine University Medical School, France

\section{Background}

$\checkmark$ Everyone is constantly exposed to several environmental exposures with positive or negative health effect.

$\checkmark$ Studies which consider this complex environmental setting are rare.

$\checkmark$ There is a scientific and political call for a realistic and "holistic" approach of cumulative exposure.

$\checkmark$ There is a need for methods able to handle cumulative exposures.

\section{Study design and data}

$\checkmark$ Lyon metropolitan area (1.2 million inhabitants, $527 \mathrm{~km}^{2}$ ), France

$\checkmark$ French census blocks (2000 inhabitants on average)

$\checkmark$ Environmental exposures groups :

- $\mathrm{NO}_{2}$ annual concentration (2 variables)

- Noise levels (3 variables)

- Traffic exposition (2 variables)

- Industrial proximity (4 variables)

- Green spaces (2 variables)

\section{Objectives}

$\checkmark$ Use data mining techniques to create a composite exposure index.

$\checkmark$ Assess the environmental burden experienced by populations in their living environment.

$\checkmark$ Illustrate this approach on a large French metropolitan area.

\section{Results (MFA)}

$\checkmark$ The four first components explain respectively $30 \%, 15 \%, 13 \%$ and $11 \%$ of the total variance

$\checkmark$ Major components interpretation:

- $1^{\text {st: }}$ air pollution and traffic proximity

- $2^{\text {nd: }}$ industrial proximity

- $3^{\text {rd: }}$ noise and green spaces

\begin{tabular}{l|ccc}
\multicolumn{1}{c}{ Components: } & $\mathbf{1}$ & $\mathbf{2}$ & $\mathbf{3}$ \\
\hline Air Pollution & 31.98 & 5.06 & 1.04 \\
\hline Noise & 15.97 & 13.23 & 68.00 \\
\hline Industrial Proximity & 0.13 & 78.34 & 5.13 \\
\hline Traffic Proximity & 32.22 & 0.38 & 1.09 \\
\hline Green Spaces & 19.71 & 2.99 & 24.74
\end{tabular}

Table 1: Contribution of each groups to the three first components (in \%)

\section{Methods}

$\checkmark$ Data mining technics, highlight underlying structures in data

$\checkmark$ Multiple Factor Analysis (MFA): analyze variables by groups, give the same weight for each group and can include both quantitative and qualitative variables.

$\checkmark$ Hierarchical Clustering (HC): minimizing the withincategory inertia and maximizing the betweencategories inertia.

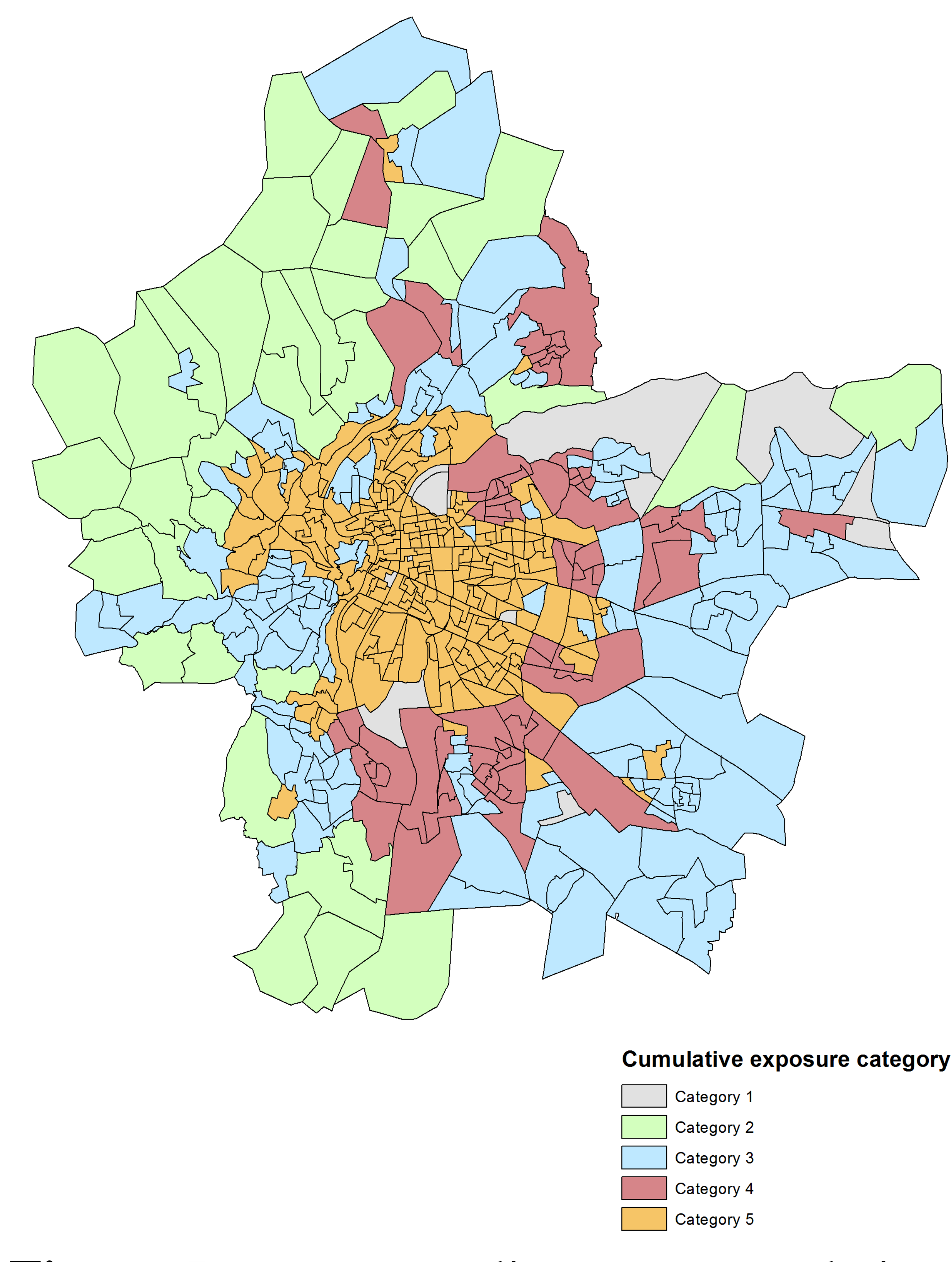

Figure: Lyon metropolitan area cumulative exposure categories created by $\mathrm{HC}$

\section{Results (HC)}

$\checkmark$ HC applied on the 10 first components of the MFA

$\checkmark 5$ cumulative exposure categories have been created using $\mathrm{HC}$

\begin{tabular}{c|ccccc} 
Category: & 1 & 2 & 3 & 4 & 5 \\
$\mathrm{NO}_{2}$ & $\approx$ & -- & -- & - & ++ \\
\hline Noise & --- & - & - & $\approx$ & + \\
\hline Traffic & -- & --- & -- & + & +++ \\
\hline Industries & - & -- & -- & +++ & --- \\
\hline Green spaces & ++ & +++ & - & - & ---
\end{tabular}

Table 2: Categories' characteristics (from +++:extremely higher than average to ---: extremely lower than average, $\approx:$ near the average value)

\section{Conclusion and perspectives}

$\checkmark$ Data analysis technics can help to obtain insight about the different exposure profiles in an area with easily performed and interpreted tools

$\checkmark$ This approach can help stakeholders to identify areas of higher "environmental burden"

$\checkmark$ As a perspective, extend to other areas and indicators of living environment (public transport accessibility, health professionals density, primary good store availability ...) 